\title{
Multiplikasi Mata Tunas Pisang 'Cavendish' In Vitro Pada Berbagai Konsentrasi Benziladenin
}

\section{In Vitro Shoot Buds Multiplication of Banana 'Cavendish' at Various Concentrations of Benzyladenine}

\section{Desi Maulida*, Lisa Erfa, dan Rizka Novi Sesanti}

Politeknik Negeri Lampung

Jl. Soekarno Hatta No.10 Rajabasa Bandar Lampung

Email : desi@polinela.ac.id

\begin{abstract}
Banana is one of the most important global agriculture commodities. Asia accounts for the production of bananas amounted to $56.4 \%$ of total banana in the world and Indonesia is one of the banana-producing countries in Asia. The demand for bananas increased need is anticipated with good cultivation techniques in order to meet domestic and international market demand. Plant regeneration in vitro tissue culture techniques or can be used to produce propagules true-to-type in large quantities in a relatively short period of time and free from disease. This research aims to study the influence of various concentrations of $B A(0,0.5,1.0$, 1.5, 2.0, 2.5, 3.0, 3.5, and $4.0 \mathrm{mg} / \mathrm{l}$ ) against the growth and reproduction of Cavendish banana propagules in vitro. Time appears buds, propagules length and the number of propagules per explant, and the number of primary roots of plants per explant observed after eight weeks of culture. The experiment results show that after explant grown for eight weeks on the media's treatment shows the different response. The increased concentration of BA can increase the number of shoots. The increased concentration of BA from $0.5 \mathrm{mg} / \mathrm{l}$ be $1-3 \mathrm{mg} / \mathrm{l}$ increased the number of propagules, but the number of propagules will decrease in the concentration of $B A$ more 3.5 or $4 \mathrm{mg} / \mathrm{l}$. In addition to BA concentration $0.5,1$ and $1.5 \mathrm{mg} / \mathrm{l} \mathrm{MS}$ media into producing shoot buds appear faster time high, highest propagules and root amount more on banana propagules Cavendish, but the number of shoots is fewer. The best of BA concentrations to induce propagules plant bananas Cavendish is $3.0 \mathrm{mg} / \mathrm{l}$.

Keywords: bananas, BA, in vitro, shoot multiplication
\end{abstract}

Disubmit : 05 Desember 2017, Diterima : 04 Januari 2018, Disetujui : 28 Januari 2018

\section{PENDAHULUAN}

Pisang (Musa sp.) merupakan salah satu tanaman budidaya paling penting untuk masyarakat yang hidup di daerah tropis dan subtropics. Pisang dikenal sebagai tanaman buah berupa herba yang berasal dari Asia Tenggara, termasuk Indonesia. Menurut BPS (2014), tanaman ini menjadi komoditi pertanian global terpenting nomor empat setelah beras, gandum dan susu. Asia menyumbang produksi pisang sebesar $56,4 \%$ dari total pisang dunia dan untuk wilayah Asia, Indonesia termasuk penghasil pisang terbesar karena $50 \%$ produksi pisang Asia dihasilkan oleh Indonesia. Produksi pisang Indonesia terus mengalami peningkatan dari tahun ke tahun. Berdasarkan data Badan Pusat Statistik (BPS, 2014), produksi tanaman pisang di Indonesia terus mengalami peningkatan dari tahun ke tahun untuk memenuhi permintaan konsumen yang juga semakin meningkat. Pada tahun 2010, 2011, 2012, 2013, dan 2014 Indonesia mampu memproduksi pisang masingmasing sebanyak 5.755.073, 6.132.695, 6.189.043, 6.279.279, dan 6.862.558 ton/tahun (BPS, 2014). 
Permintaan akan pisang yang terus meningkat perlu diantisipasi dengan teknik budidaya yang baik guna memenuhi permintaan pasar domestik dan internasional. Perbanyakan bibit pisang secara konvensional dengan menggunakan anakan atau bonggol membutuhkan waktu yang relatif lama. Namun cara ini berpotensi untuk terbawanya inokulum penyakit dan kurang dapat memenuhi permintaan bibit dalam jumlah besar dalam waktu relatif singkat

Salah satu alternatif penyediaan bibit pisang yang cepat adalah dengan teknik perbanyakan tanaman secara in vitro. Kultur jaringan merupakan suatu teknik untuk menumbuhkembangkan bagian tanaman in vitro secara aseptik dan aksenik pada media kultur berisi hara lengkap dan kondisi lingkungan terkendali untuk tujuan tertentu. Kultur jaringan bermula pada teori totipotensi sel yang dikemukaan oleh Schwann dan Schleiden bahwa setiap sel tanaman hidup mempunyai informasi genetik dan perangkat fisiologis lengkap untuk dapat tumbuh dan berkembang menjadi tanaman utuh pada kondisi sesuai. Teknik ini mampu menghasilkan banyak tanaman dalam waktu yang relatif singkat, tidak memerlukan tempat yang luas, kegiatan perbanyakan dapat dilakukan sepanjang tahun tanpa bergantung pada musim, dan menghasilkan bibit yang sehat. Perbanyakan dengan kultur jaringan menjadi pilihan tepat ketika permintaan pasar terhadap suatu tanaman tinggi tetapi pasokannya rendah karena laju perbanyakannya secara konvensional dianggap lambat (Yusnita, 2003).

Perbanyakan tanaman dengan teknik kultur jaringan terbagi atas beberapa tahapan, yaitu: inisiasi kultur eksplan, multiplikasi, perakaran dan terakhir adalah aklimatisasi planlet. Zat pengatur tumbuh baik eksogen dan endogen sangat bepengaruh pada tahap multiplikasi. Untuk membantu percepatan pembentukan mata tunas dan tunas (propagul) umumnya dibantu oleh ZPT jenis sitokinin, seperti benziladenin (BA), kinetin, isopenteniladenin (2-iP), dan thidiazuron (TDZ). Dari berbagai sitokinin tersebut, BA menjadi sitokinin yang paling sering digunakan karena efektifitas untuk perbanyakan propagul cukup tinggi, mudah didapat, dan relatif lebih murah dibanding jenis sitokinin lain.

Kebutuhan akan jenis dan konsentrasi auksin dan atau sitokinin sebagai stimuli dalam regenerasi organ (tunas/akar) bersifat species-specific tergantung genotipe tanaman yang dikulturkan (Yusnita et al., 2015). Beberapa hasil penelitian menunjukkan bahwa BA dapat meningkatkan jumlah propagul pisang secara dratis, namun konsentrasinya beragam untuk setiap genotype untuk setiap kultivar tanaman pisang Yusnita et al. (2015) melaporkan bahwa media MS+5 mg/l BA merupakan media terbaik dalam proliferasi propagul untuk kultivar pisang Ambon Kuning (40,7 propagul) dan Raja Bulu (12,3 peopagul). Sipen and Davey (2012), menyatakan bahwa peningkatan konsentrasi BA diikuti dengan peningkatan jumlah tunas $(0-6 \mathrm{mg} / \mathrm{l})$ pada 4 kultivar pisang (pisang barangan, pisang nangka, pisang mas, dan pisang awak). Pada penelitian ini akan dipelajari pengaruh berbagai konsentrasi BA pada multiplikasi pisang Cavendish secara in vitro.

\section{METODE PENELITIAN}

Penelitian ini dilaksanakan di laboratorium kultur jaringan tanaman, Jurusan Budidaya Tanaman Pangan, Politeknik Negeri Lampung. Bahan tanaman yang digunakan dalam percobaan ini adalah potongan mata tunas pisang Cavendish berukuran $1 \mathrm{~cm} \times 1 \mathrm{~cm}$. Potongan mata tunas tersebut diisolasi dari kultur tunas aseptik pisang Cavendish dalam kultur in vitro yang didapatkan dari Laboratorium Kultur Jaringan Polinela.

Media dasar yang digunakan adalah formulasi media yang berisi garam-garam makro dan mikro MS (Murashige and Skoog, 1962) dengan $30 \mathrm{~g} / \mathrm{l}$ sukrosa, 0,5 mg/l piridoksin-HCl, $2 \mathrm{mg} / \mathrm{l}$ glisin, 0,5 mg/l asam nikotinat , $0,1 \mathrm{mg} / \mathrm{l}$ thiamin- $\mathrm{HCl}$, dan $100 \mathrm{mg} / \mathrm{l}$ mio-inositol. Media induksi propagul adalah media MS yang ditambah dengan berbagai konsentrasi BA (0, 0,5, 1,0, 1,5, 2,0, 2,5, 3,0 dan 4,0 mg/l). Media diatur pH-nya menjadi 5,8 sebelum ditambahkan $7 \mathrm{~g} / \mathrm{l}$ bubuk agar. Media dididihkan, lalu dimasukkan ke dalam botol-botol kultur $250 \mathrm{ml}$, sebanyak $30 \mathrm{ml}$ per botol. Botol yang berisi media ditutup dengan plastik bening tahan panas, diikat dengan karet, dan disterilisasi dalam autoklaf selama 20 menit pada suhu $121^{\circ} \mathrm{C}$ dan tekanan $1,2 \mathrm{kgf} \mathrm{cm}^{-}$

2. Eksplan potongan propagul $(1 \mathrm{~cm} \mathrm{x} 1 \mathrm{~cm})$ ditanam pada media inisiasi yaitu media perlakuan. 
Percobaan disusun berdasarkan rancangan acak lengkap satu faktor, yaitu konsentrasi BA dengan delapan taraf $(0,0,5,1,0,1,5,2,0,2,5,3,0$ dan 4,0 mg L-1). Masing-masing perlakuan diulang tiga kali. Setiap satuan percobaan terdiri dari 3 botol kultur yang masing-masing berisi 2 eksplan. Pengamatan dilakukan pada umur 8 minggu setelah penanaman eksplan. Variabel yang diamati adalah waktu munculnya mata tunas, ratarata tinggi propagul, jumlah propagul per eksplan, dan jumlah akar tanaman per eksplan. Mata tunas adalah bakal tunas (panjang kurang dari $1 \mathrm{~cm}$ ) tunas adalah mata tunas yg sudah memanjang $(1 \mathrm{~cm}$ atau lebih). Propagul adalah gabungan mata tunas dan tunas. Pengamatan dilakukan pada saat kultur berumur 8 minggu setelah tanam (MST). Data dari setiap variabel pengamatan dianalisis ragam dan jika terdapat perbedaan nyata antar-perlakuan, maka pemisahan nilai tengah dilakukan dengan uji BNT pada taraf 0,05.

\section{HASIL DAN PEMBAHASAN}

Eksplan pisang berupa potongan propagul yang ditanam di media perlakuan berbeda mulai menunjukkan pertumbuhan propagul setelah berumur kurang lebih 6 hari setelah tanam. Pada minggu-minggu berikutnya hingga minggu ke 8 setelah tanam, eksplan menunjukkan respons pertumbuhan dan perkembangan lebih lanjut yang berbeda-beda terhadap berbagai perlakuan yang dicobakan.

Media MS dengan penambahan BA $0,5 \mathrm{mg} / \mathrm{l}$ secara umum menghasilkan pertumbuhan yang lebih baik, yang ditunjukkan oleh waktu munculnya mata tunas lebih cepat, rata-rata propagul tertinggi, menghasilkan banyak akar daripada propagul di media dengan penambahan konsentrasi sitokinin BA lainnya. Media MS dengan penambahan BA $(2,0,2,5$, dan 3,0 mg/l) umumnya menghasilkan propagul dengan jumlah propagul berkisar antara 25 hingga 27 propagul per eksplan. Namun propagul yang terbentuk tersebut umumnya lebih pendek daripada propagul di media tanpa ZPT. Hampir semua propagul yang tumbuh di media dengan penambahan sitokinin berakar dengan jumlah sangat sedikit. Representasi penampilan kultur pisang Cavendish di media MS dengan berbagai konsentrasi BA disajikan pada Gambar 1.
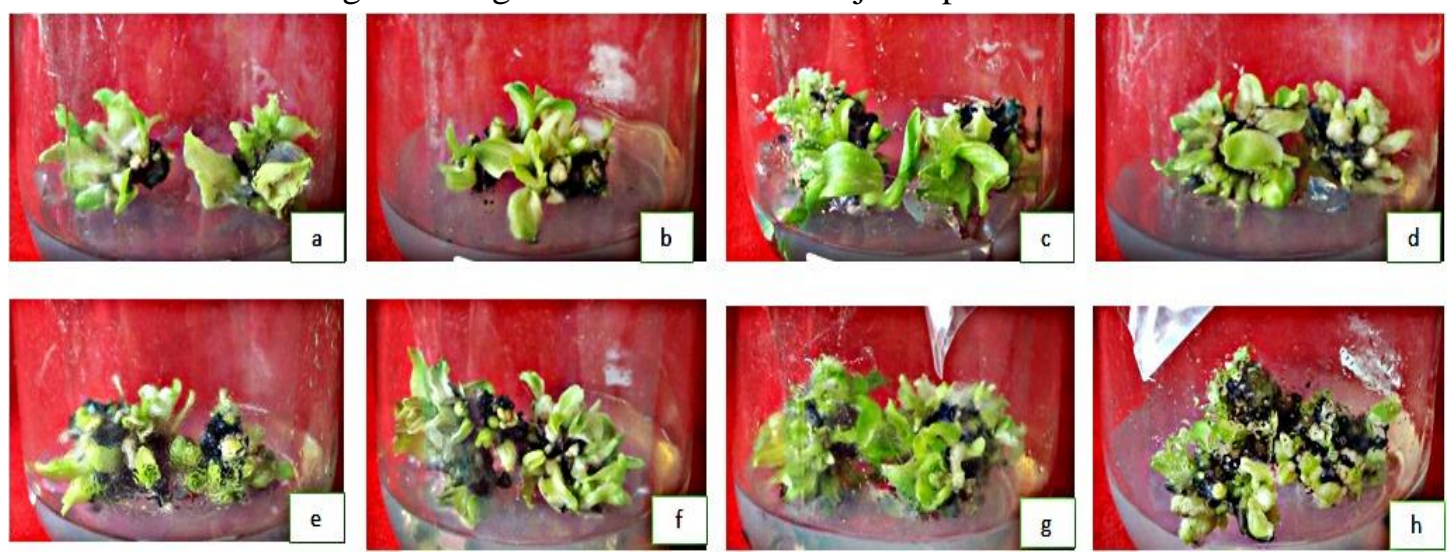

Gambar 1. Penampilan kultur pisang Cavendish di media (a) MS + BA 0,5 mg/l, (b) MS + BA 1,0 mg/l, (c) MS + BA 1,5 mg/l, (d) MS + BA 2,0 mg/l, (e) MS + BA 2,5 mg/l, (f) MS + BA 3,0 mg/l, (g) MS + BA 3,5 mg/l, dan (h) MS + BA 4,0 mg/l pada umur 8 minggu.

Hasil analisis ragam menunjukkan bahwa perbedaan konsentrasi BA berpengaruh nyata terhadap waktu muncul mata tunas, tinggi propagul, jumlah akar, dan jumlah propagul per eksplan. Rekapitulasi hasil pengamatan pengaruh BA terhadap pertumbuhan dan perbanyakan propagul pisang Cavendish disajikan pada Tabel 1 .

Berdasarkan hasil pemisahan nilai tengah dengan BNT taraf 5\% diketahui bahwa eksplan yang ditanam pada media $0,5 \mathrm{mg} / \mathrm{l}$ BA memiliki waktu muncul propagul tercepat, propagul tertinggi dan jumlah akar yang lebih banyak dibandingkan perlakuan lainnya, diikuti dengan media 1,0 atau 1,5 mg/l BA. Hal ini diduga karena penambahan sitokinin dengan konsentrasi yang lebih rendah ke dalam media MS, tidak menghambat pertumbuhan propagul dan tumbuh memanjang tanpa diikuti multiplikasi propagul yang lebih banyak. Hasil 
ini sejalan dengan penelitian Ferdous et al. (2015), yang melaporkan bahwa konsentrasi 0,5 mg/l BA dapat menghasilkan tunas tunggal dan tinggi tunas tertinggi pada pisang "Sabri".

Tabel 1. Pengaruh benziladenin (BA) terhadap pertumbuhan dan perbanyakan propagul pisang Cavendish in vitro pada 8 minggu pengulturan.

\begin{tabular}{llcccc}
\hline No & \multicolumn{1}{c}{ Perlakuan } & $\begin{array}{c}\text { Waktu muncul } \\
\text { mata tunas } \\
\text { (hari) }\end{array}$ & $\begin{array}{c}\text { Jumlah } \\
\text { propagul/eksplan } \\
\text { (propagul) }\end{array}$ & $\begin{array}{c}\text { Jumlah } \\
\text { akar/eksplan } \\
\text { (helai) }\end{array}$ & $\begin{array}{c}\text { Tinggi } \\
\text { propagul/eksplan } \\
\text { (cm) }\end{array}$ \\
\hline 1 & MS+0,5 mg/l BA & $6.22 \mathrm{c}$ & $18,17 \mathrm{f}$ & $3,83 \mathrm{a}$ & $0,82 \mathrm{a}$ \\
2 & MS+1 mg/l BA & $6.56 \mathrm{c}$ & $20,28 \mathrm{e}$ & $2,61 \mathrm{~b}$ & $0,54 \mathrm{~b}$ \\
3 & MS+1,5 mg/l BA & $7.22 \mathrm{c}$ & $21,94 \mathrm{~d}$ & $0,61 \mathrm{c}$ & $0,51 \mathrm{~b}$ \\
4 & MS+2 mg/l BA & $9.44 \mathrm{~b}$ & $25,83 \mathrm{~b}$ & $0,17 \mathrm{de}$ & $0,26 \mathrm{e}$ \\
5 & MS+2,5 mg/l BA & $9.33 \mathrm{~b}$ & $26,39 \mathrm{ab}$ & $0,11 \mathrm{e}$ & $0,34 \mathrm{~cd}$ \\
6 & MS+3 mg/l BA & $9.56 \mathrm{~b}$ & $26,78 \mathrm{a}$ & $0,44 \mathrm{~cd}$ & $0,38 \mathrm{c}$ \\
7 & MS+3,5 mg/l BA & $10.67 \mathrm{~b}$ & $23,11 \mathrm{c}$ & $0,33 \mathrm{cde}$ & $0,40 \mathrm{c}$ \\
8 & MS+4 mg/l BA & $13.89 \mathrm{a}$ & $22,61 \mathrm{~cd}$ & $0,39 \mathrm{cde}$ & $0,34 \mathrm{~cd}$ \\
\hline
\end{tabular}

Keterangan : angka berbeda menunjukkan bahwa perlakuan berbeda nyata $(\mathrm{P}<0.05)$

Peningkatan konsentrasi BA pada media MS umumnya menghasilkan tunas-tunas tanpa akar, atau jika berakar jumlahnya hanya 1 atau 2 helai. Hal ini diduga karena BA merupakan golongan sitokinin yang berperan terhadap pembentukan tunas dan menghambat pembentukan akar. Keadaan ini membuktikan bahwa BA mampu menekan pertumbuhan akar. Kemampuan menghambat pertumbuhan akar ini sangat penting untuk penggandaan tunas. BA merupakan jenis zat pengatur tumbuh golongan sitokinin yang pada kebanyakan tanaman berperan untuk merangsang pembentukan tunas aksilar maupun tunas adventif (Hapsoro and Yusnita, 2016).

Beberapa penelitian terkait dengan BA pada perbanyakan tunas berbagai pisang in vitro menyebutkan bahwa konsentrasi BA yang semakin tinggi dapat menghasilkan tunas pisang yang semakin banyak pada konsentrasi optimum tertentu. Dosis ini berbeda untuk setiap jenis pisang, karena kebutuhan akan jenis dan konsentrasi sitokinin untuk merangsang tunas aksilar bersifat spesies-spesific, atau bahkan spesifik untuk varietas tertentu, sebagaimana yang dikemukakan oleh (Gahan and George, 2008) bahwa zat pengatur tumbuh yang paling sesuai untuk perbanyakan tanaman in vitro yang paling sesuai seringkali spesifik untuk spesies atau bahkan spesifik untuk kultivar tertentu dalam satu spesies. Penelitian sebelumnya Avivi and Ikrarwati (2004), melaporkan bahwa peningkatan parameter jumlah tunas pisang 'Abaca' terjadi pada konsentrasi 4, 5, dan $6 \mathrm{mg} / \mathrm{l}$ lalu penurunan jumlah tunas terjadi pada konsentrasi $7 \mathrm{mg} / \mathrm{l}$ BA. Penelitian Muhammad et al., (2007) pada pisang 'Basrai' menunjukkan bahwa pada konsentrasi 2, 4, dan 6 mg/l terjadi peningkatan jumlah tunas pisang kemudian penurunan jumlah tunas terjadi pada konsentrasi 8 mg/l BA.

Hasil penelitian ini menunjukkan bahwa penambahan konsentrasi BA ke dalam media kultur meningkatkan jumlah propagul pada kultur pisang Cavendish tanaman pada 8 minggu. Hasil ini konsisten dengan beberapa laporan terdahulu pada kultur jaringan Cavendish maupun tanaman-tanaman lain. Sari (2012) menyatakan bahwa peningkatan konsentrasi BA (2, 4, $6 \mathrm{mg} / \mathrm{l})$ menyebabkan terjadi peningkatan jumlah tunas pisang 'Ambon Kuning”. Media MS dengan penambahan BA 2-3 mg/l menghasilkan propagul terbanyak, sedangkan perlakuan 3,5-4 mg/l BA menghasilkan propagul lebih sedikit, tetapi masih lebih banyak daripada 0,5-1,5 mg/l BA. Hasil serupa dilaporkan oleh (Kalimuthu et al., 2007) yang menyatakan bahwa konsentrasi BA terbaik untuk menginduksi tunas tanaman pisang "Cavendish Dwarf" adalah 3,0 mg/l, dan kemudian menurun pada konsentrasi BA lebih dari 3,0 mg/l. 
Staden et al. (2008) menjelaskan bahwa dalam perbanyakan tanaman in vitro, perolehan tunas adventif atau tunas aksilar yang paling banyak karena menggunakan sitokinin pada konsentrasi tertentu tidak berarti yang terbaik, karena seringkali tunas-tunas yang dihasilkan mempunyai internode yang pendek dengan kualitas yang kurang bagus. Dalam penelitian ini propagul yang dihasilkan pada media dengan penambahan BA 2-4 $\mathrm{mg} / \mathrm{l}$ jauh lebih pendek daripada propagul yang dihasilkan di media MS dengan penambahan 0,5-1,5 mg/l BA, propagul tersebut dapat tumbuh normal memanjang ketika disubkultur ke media MS tanpa ZPT, baik dengan atau tanpa arang aktif. Taji et al. (2002) juga membahas, bahwa untuk mengatasi masalah kualitas tunas yang kurang bagus dapat dilakukan dengan subkultur ke media dengan konsentrasi sitokinin lebih rendah atau ke media tanpa ZPT.

\section{KESIMPULAN}

Peningkatan konsentrasi BA, dapat meningkatkan jumlah propagul sampai konsentrasi optimum tertentu. Peningkatan konsentrasi BA dari $0,5 \mathrm{mg} / \mathrm{l}$ menjadi $1-3 \mathrm{mg} / \mathrm{l}$ menambah jumlah propagul, namun jumlah propagul akan menurun apabila konsentrasi BA lebih 3,5 atau $4 \mathrm{mg} / \mathrm{l}$. Penambahan BA konsentrasi 0,5, 1, dan 1,5 mg/l ke dalam media MS menghasilkan waktu muncul propagul lebih cepat, propagul tertinggi, dan jumlah akar lebih banyak pada propagul pisang Cavendish, namun jumlah propagul lebih sedikit. Konsentrasi BA terbaik untuk menginduksi propagul tanaman pisang Cavendish adalah $3.0 \mathrm{mg} / \mathrm{l}$.

\section{DAFTAR PUSTAKA}

Avivi, S., Ikrarwati, I., 2004. Mikropropagasi pisang Abaca (Musa textilis Nee) melalui teknik kultur jaringan. Ilmu Pertan. 11, 17-34.

BPS, 2014. Tabel Dinamis [WWW Document]. URL http://www.bps.go.id/site/pilihdata (accessed 1.25.18).

Ferdous, M.H., Billah, A.A.M., Mehraj, H., Taufique, T., Uddin, A.F.M.J., 2015. BAP and IBA pulsing for in vitro multiplication of banana cultivars through shoot-tip culture. J. Biosci. Agric. Res. 3, 87-95.

Gahan, P.B., George, E.F., 2008. Adventitious Regeneration, in: George, E.F., Hall, M.A., Klerk, G.-J. De (Eds.), Plant Propagation by Tissue Culture Volume 1. The Background. Springer, The Netherlands, pp. 355-401.

Hapsoro, D., Yusnita, 2016. Kultur Jaringan Untuk Perbanyakan Klonal Kelapa Sawit (Elaeis guineesis Jacq.). CV. Anugrah Utama Raharja (AURA), Bandar Lampung.

Kalimuthu, K., Saravanakumar, M., Senthilkumar, R., 2007. In Vitro Micropropagation of Musa sapientum L. (Cavendish Dwarf). African J. Biotechnol. 6, 1106-1109.

Muhammad, A., Rashid, H., Hussain, I., 2007. Proliferation-rate Effects of BAP and Kinetin on Banana (Musa spp. AAA Group) 'Basrai.' HORTSCIENCE 42, 1253-1255.

Murashige, T., Skoog, F., 1962. A revised medium for rapid growth and bioassays with tobacco tissue cultures. Physiol. Plant. 15, 473-497.

Sari, E.P., 2012. Multiplikasi Tunas Pisang Ambon Kuning Sebagai Respons Terhadap Konsentrasi Benzyladenine Dan Indole-3-Acetic Acid. Universitas Lampung.

Sipen, P., Davey, M.R., 2012. Effects of N6-benzylaminopurine and indoleacetic acid on in vitro shoot multiplication, nodule-like meristem proliferation and plant regeneration of Malaysian bananas. Trop Life Sci Res 23, 67-80.

Staden, J. Van, Zazimalova, E., George, E.F., 2008. Plant Growth Regulators II: Cytokinins, their Analogues and Antagonists, in: George, E.F., Hall, M.A., Klerk, G.-J. De (Eds.), Plant Propagation By Tissue Culture 3rd Edition. Springer, The Netherlands, pp. 205-226. 
Maulida dkk : Multiplikasi Mata Tunas Pisang 'Cavendish' In Vitro Pada Berbagai Konsentrasi Benziladenin

Taji, A., Kumar, P.P., Lakshmanan, P., 2002. In vitro plant breeding. Food Products Press, New York.

Yusnita, 2003. Kultur Jaringan: Cara Memperbanyak Tanaman secara Efisien. AgroMedia Pustaka, Jakarta.

Yusnita, Y., Danial, E., Hapsoro, D., 2015. In Vitro Shoot Regeneration of Indonesian Bananas (Musa spp.) cv. Ambon Kuning and Raja Bulu, Plantlet Acclimatizationand Field Performance. Agrivita 37, 5158. https://doi.org/DOI: http://doi.org/10.17503/agrivita.v37i1.438 